caused by acute fatty liver of pregnancy. Epidural anaesthesia is preferable, and should be preceded when necessary by transfusion of fresh-frozen plasma and fresh platelet concentrate to avoid excessive bleeding during delivery. In other respects the management of fulminant hepatic failure is the same as in nonpregnant women. ${ }^{13}$

ROGER WILLIAMS R J EDE

Liver Unit,

King's College Hospital Medical School,

London SE5 8RX

Khuroo MS, Teli MR, Skidmore S, Sofi MA, Khuroo MI. Incidence and severity of viral hepatitis in pregnancy. Am 7 Med $1981 ; 70: 252-5$.

- Sever J, White LR. Intrauterine viral infections. Annu Rev Med 1968;19: 471-8.

${ }^{3}$ Haemmerli UP. Jaundice during pregnancy. Acta Med Scand 1966;179, suppl 444:9-111.

' Borhanmanesh F, Haghighi P, Hekmat K, Rezaizadeh K, Ghavami AG. Viral hepatitis during pregnancy. Gastroenterology 1973;64:304-12.

s Siegel M, Fuerst HT, Peress NS. Comparative fetal mortality in maternal virus diseases. A prospective study on rubella, measles, mumps, chicken pox and hepatitis. $N$ Engl 7 Med 1966;274:768-71.

- Hieber JP, Dalton D, Shorey J, Combes B. Hepatitis and pregnancy. $\mathcal{F}$ Pediatr 1977;91:545-9.

${ }^{7}$ Stoller A, Collmann RD. Incidence of infective hepatitis followed by Down's syndrome nine months later. Lancet 1965;ii:1221-30.

${ }^{8}$ Dietzman DE, Madden DL, Sever JL, Lander JJ, Purcell RH. Lack of relationship between Down's syndrome and maternal exposure to Australia antigen. Am $\mathcal{f}$ Dis Child 1972;124:195-7.

${ }^{9}$ Stevens CE, Beasley RP, Tsui J, Lee W-C. Vertical transmission of hepatitis B antigen in Taiwan. N Engl f Med 1975;292:771-4.

1" Derso A, Boxall EH, Tarlow MJ, Flewett TH. Transmission of HBsAg from mother to infant in four ethnic groups. Br Med f 1978;i:949-52.

$"$ Alberti A, Diana S, Scullard GH, Eddleston ALWF, Williams R. Full and empty Dane particles in chronic hepatitis $B$ virus infection : relation to hepatitis B e antigen and presence of liver change. Gastroenterology 1978;75:869-74.

12 Beasley RP, Stevens CE. Vertical transmission of HBV and interruption with globulin. In: Vyas GN, Cohen SN, Schmid R, eds. Virul hepatitis. Tunbridge Wells: Abacus Press, 1979:333-45.

${ }^{13}$ Braude S, Gimson AES, Williams R. Progress in the management of fulminant hepatic failure. Intensive Care Med 1981;7:101-3.

\section{Acute ileitis}

Acute ileitis is relatively rare. Its incidence is one case per million population ${ }^{1}$ compared with 40 to 80 per million for Crohn's disease. ${ }^{2}$ Furthermore, acute terminal ileitis usually resolves spontaneously and does not show the chronicity of Crohn's disease. The two conditions cannot always be distinguished: patients with Crohn's disease can present acutely with symptoms resembling appendicitis, and a diagnostic overlap is likely to persist until the cause of Crohn's disease is determined. In some series $10-20 \%$ of patients with acute terminal ileitis go on to develop Crohn's disease. ${ }^{4-6}$

The commonest identifiable cause of acute terminal ileitis is infection by Yersinia enterocolitica ${ }^{7}$ and $Y$ pseudotuberculosis, ${ }^{8}$ which accounts for 50 to $80 \%$ of cases. ${ }^{9}$ Yersinia are Gramnegative rods resembling non-lactose-fermenting Escherichia coli in morphology. Clinicians are becoming more aware of yersinia infections, which are being diagnosed more often. Only $0.5 \%$ of 475 patients with abdominal symptoms seen in 1975 were found to have antibodies to $Y$ enterocolitica compared with $2 \cdot 7 \%$ of sera from 1233 patients examined in 1980 at the yersinia reference laboratory in Leicester (N S Mair, "Yersinia infection in the UK and Eire with special reference to yersinia enterocolitica," paper given at the WHO meeting in Paris in April 1981). The clinical manifestations of yersinia infection include acute enteritis, fever, and diarrhoea in children, and an acute terminal ileitis or mesenteric adenitis in adults. Some patients have associated erythema nodosum and polyarthritis. ${ }^{10}$ Many of the patients have operations for appendicitis suspected on clinical grounds; typically the surgeon finds an inflamed terminal ileum, with local lymphadenopathy. The appendix and caecum may also be affected.

The cause of the acute ileitis cannot be determined from the macroscopic appearances. Appendicectomy should be performed in these cases; it does not increase the risk of fistula formation even if the patient has Crohn's disease. Fistula formation in Crohn's disease is related to the severity of the disease in the ileum and develops from the ileum and not the appendiceal stalk. ${ }^{11}$ The radiological characteristics of yersinia infection $^{12}$ are a nodular pattern of the terminal ileum reflecting oedema of the bowel, hyperplasia of intestinal lymphoid tissue, and enlargement of regional lymph nodes. These features also occur in Crohn's disease. Nevertheless, abscess or fistula formation, stenosis, pseudodiverticula, skip lesions, and signs of appreciable thickening of the intestinal wall are never observed in yersinia ileitis. The histological features of infection with $Y$ enterocolitica are non-specific transmural inflammation with a predominant polymorph infiltrate and mucosal ulceration. ${ }^{13}$ Granuloma formation is not found even in serial sections. When the organism responsible is $Y$ pseudotuberculosis four histological stages may be distinguished: lymphoid hyperplasia, diffuse histiocytic cell hyperplasia, epithelioid granuloma, and central coagulative necrosis of the granuloma with abscess formation. ${ }^{14}$

When the colon is affected small ulcers, resembling aphthoid ulcers of Crohn's disease, may be seen on sigmoidoscopy or colonoscopy, but yersinia infection rarely mimics colonic Crohn's disease. ${ }^{15}$ The diagnosis is made by culturing the organism from the stool or from a swab at appendicectomy. Circulating antibodies to $Y$ enterocolitica may be detected after six to seven days and their titre shows a peak at two to three weeks; a rising titre is diagnostic. Titres of 1/50 may be found in asymptomatic patients, but titres of $1 / 100$ or greater are associated with clinical disease (N S Mair). The blood test may need to be repeated to make the diagnosis. In contrast, antibodies to $Y$ pseudotuberculosis are usually present with the onset of symptoms. Yersinia infection usually resolves spontaneously, with patients becoming symptom free after two to three weeks. Tetracycline is the drug of choice for patients with complications such as erythema nodosum, polyarthritis, persisting diarrhoea, and fever. ${ }^{8} 9$ Yersinia infection never progresses to Crohn's disease. ${ }^{10}$ Recurrence of symptoms, chronicity, or late complications related to the gastrointestinal tract do not occur. An acute arthritis caused by $Y$ enterocolitica infection may nevertheless cause long-term complications, including ankylosing spondylitis, sacroiliitis, and even seropositive rheumatoid arthritis. ${ }^{16}$

If infection with yersinia is not found other conditions that then cause terminal ileitis should be considered, such as tuberculosis, tularaemia, amoebiasis, actinomycosis, schistosomiasis, and infestation with the larvae of the fish nematode Anisakis. Crohn's disease has been reported as presenting acutely with symptoms of acute appendicitis and free perforation ${ }^{17}$; so that in patients in whom no other cause is found the wheel turns full circle.

C 6 MORÁIN

Honorary Senior Registrar,

Division of Clinical Sciences,

Clinical Research Centre,

London HA1 3UJ

${ }^{1}$ Höj L, Jensen PB, Bonnevie O, Riis P. An epidemiological study of regional enteritis and acute ileitis in Copenhagen County. Scand $\mathcal{f}$ Gastroenterol 1973;8:381-4. 
${ }^{2}$ Kyle J, Stark G. Fall in the incidence of Crohn's disease. Gut 1980;21 : 340-3.

${ }^{3}$ Mayberry JF, Rhodes J, Hughes LE. Incidence of Crohn's disease in Cardiff between 1934 and 1977. Gut $1979 ; 20: 602-8$.

${ }^{4}$ Crohn BB. The pathology of acute regional ileitis. American fournal of Digestive Diseases 1965;10:565-72.

${ }^{5}$ Sjoestrom B. Acute terminal ileitis and its relation to Crohn's disease. In: Engel A, Larsson T, eds. Regional enteritis (Crohn's disease). 5th Skandia International Symposium, Stockholm, 1970. Stockholm: Nordiska Bokhandeln Förlag, 1971:73-80.

${ }^{6}$ Kewenter J, Hultén L, Kock NG. The relationship and epidemiology of acute terminal ileitis and Crohn's disease. Gut 1974;15:801-4.

7 Winblad S, Niiehn B, Sternby NH. Yersinia enterocolitica (Pasteurella X) in human enteric infections. Br Med f 1966; ;i:1363-6.

${ }^{8}$ Gurry JF. Acute terminal ileitis and yersinia infection. Br Med $\mathcal{F} 1974$;ii: 264-6.

${ }^{9} \mathrm{Jess}$ P. Acute terminal ileitis. A review of recent literature on relationship to Crohn's disease. Scand $\mathcal{F}$ Gastroenterol 1981;16:321-4.

10 Vantrappen G, Agg HO, Ponette E, Geboes K, Bertrand Ph. Yersinia enteritis and enterocolitis: gastroenterological aspects. Gastroenterology $1977 ; 72: 220-7$

11 Gump FE, Lepore M, Barker HG. A revised concept of acute regional enteritis. Ann Surg 1967;166:942-6.

12 Ekberg O, Sjöström B, Brahme F. Radiological findings in yersinia ileitis. Radiology 1977;123:15-9.

${ }^{13}$ Bradford WD, Noce PS, Gutman LT. Pathologic features of enteric infection with Yersinia enterocolitica. Archives of Pathology 1974;98: 17-22.

${ }^{14}$ El-Maraghi NRH, Mair NS. The histopathology of enteric infection with Yersinia pseudotuberculosis. Am f Clin Pathol 1979;71:631-4.

15 Swarbrick ET, Kingham JGC, Price HL, et al. Chlamydia, cytomegalovirus, and yersinia in inflammatory bowel disease. Lancet 1979;ii:11-2.

${ }^{16}$ Marsal L, Winblad S, Wollheim FA. Yersinia enterocolitica arthritis in southern Sweden: a four-year follow-up study. $\mathrm{Br} M e d \mathcal{F} 1981 ; 283$ : 101-3.

17 Janevicius RV, Bartolome JS, Schmitz RL. Acute free perforation as a presenting sign of regional enteritis. Case report and collective review of the literature. Am $\mathcal{F}$ Gastroenterol 1980;74:143-9.

\section{Caesarean section}

The proportion of babies delivered by caesarean section has been rising steadily in Britain and North America for many years. In 1963 in England and Wales the figure was 3.1\%, and by 1978 it had risen to $7 \cdot 5 \% .^{2}$ In the United States the rise has been even more dramatic-from 5.5\% in 1970 to $15.2 \%$ in 1978-and it is continuing. ${ }^{3}$ These are national figures. In individual hospitals the rates vary greatly and reflect the practice of the medical staff as well as the types of patients they are dealing with.

The fact that caesarean section is safer than it has ever been contributes to its increased use. But it remains a major surgical procedure that is not without risk. The death rate for 1000 caesarean sections in England and Wales fell from 1.3 in 1964 to 0.7 in $1975,{ }^{4}$ and the figures in the United States are broadly comparable. ${ }^{35}$ This is several times the overall maternal death rate for England and Wales, which was 0.1 per 1000 total births in $1975 .{ }^{4}$ We cannot, of course, compare direct the figures for the two methods of delivery or even determine the inherent risk of elective caesarean section, where so much depends on the patient's condition, the skill of the operator, and, not least, the experience and skill of the anaesthetist. Some of the maternal deaths that occur after caesarean section can reasonably be attributed to the complications that necessitated the operation, but the series of Report on Confidential Enquiries into Maternal Deaths in England and Wales has shown an increasing percentage of deaths with avoidable factors: in 1952-4, 30\% were judged to have avoidable factors, but more recent reports give proportions of $50 \%$ and even $60 \%{ }^{4}$ (Regional assessors, after considering the circumstances of each death, record an avoidable factor when there was a departure from accepted standards of satisfactory care and where an alternative form of management might have prevented or reduced the likelihood of death.) The same series of reports has given more precise information about the causes of death in these cases. Some complication associated with the anaesthetic is the most frequent single cause of death after caesarean section-it accounts for $20 \%$ of all deaths. This cause of death is doubly important in that avoidable factors are present in all but a few cases. Haemorrhage and sepsis are the other causes that are largely avoidable; pulmonary embolism is a partly avoidable cause. ${ }^{45}$

The choice between vaginal and abdominal delivery depends on how the obstetrician sees the balance of risks, and the decision is personal and specific to a given case. One important factor is his concern to avoid any accusation of failure to intervene when caesarean section might arguably have led to safer delivery for the mother and especially for the child. Conceivably electronic fetal monitoring, ${ }^{6}$ used uncritically, could have led to an increase in caesarean sections. ${ }^{2}$ Another noticeable development is the delivery of more breech babies, especially small ones, by caesarean section. $^{89}$

The wisdom of this increase in the proportion of abdominal deliveries has been challenged by Francome and Huntingford, ${ }^{6}$ who remain unconvinced that the trend is in the best interests of mothers or babies. On the basis of their own experience in London and a review of reports of other series they do not believe that a case has yet been made for a caesarean section rate over $6 \%$. Quoting Baird's assessment of social influences on the efficiency of reproduction, ${ }^{10}$ they argue that the improvements in maternal and fetal mortality rates in the past 25 years have come more from socioeconomic progress than from readier recourse to surgical intervention. Their challenge of the evidence on which the increasing trend towards delivery by caesarean section is based is refreshing and helpful. As with other techniques of intervention in labour, we need more sound, scientific evidence that caesarean section is in the best interests of mother and child. In the meantime the obstetrician must decide on the safest method of delivery by weighing up all the considerations in the individual case-keeping in mind his own experience and the facilities available to him.

Professor of Obstetrics and Gynaecology,

J K RUSSELL

University of Newcastle upon Tyne,

Princess Mary Maternity Hospital,

Newcastle upon Tyne NE2 3BD

1 General Register Office. Report on hospital in-patient enquiry 1963. London: Ministry of Health and General Register Office, 1967.

2 Office of Population Censuses and Surveys. Maternity statistics 1978. London: OPCS, 1981 (OPCS Monitor MB4 81/1.)

${ }^{3}$ National Institutes of Health. Cesarean childbirth. Consensus developmen conference summary. Vol 3. No 6. Bethesda: National Institutes of Health, 1981.

4 Department of Health and Social Security. Report on confidential enquiries into maternal deaths in England and Wales 1973-1975. London: HMSO, 1979. (Reports on Health and Social Subjects, No. 14.)

${ }^{5}$ Rubin GL, Peterson HB, Rochat RW, McCarthy BJ, Terry JS. Maternal death after cesarean section in Georgia. Am $\mathcal{F}$ Obstet Gynecol $1981 ; 139$ : $681-5$.

${ }^{6}$ Francome C, Huntingford APJ. Birth by caesarean section in the United States of America and in Britain. $\mathcal{F}$ Biosoc Sci 1980;12:353-62.

7 Jones OH. Cesarean section in present-day obstetrics. Am $\mathcal{F}$ Obstet Gynecol $1976 ; 126: 521-30$.

${ }^{8}$ Karp LE, Doney JR, McCarthy T, Meis PJ, Hall M. The premature breech: trial of labor or cesarean section? Obstet Gynecol 1979;53: 88-92.

9 Ingemarsson I, Westgren M, Svenningsen NW. Long-term follow-up of preterm infants in breech presentation delivered by caesarean section. A prospective study. Lancet 1978 ;ii:172-5.

10 Baird D. The evolution of modern obstetrics. Lancet 1960;ii:557-64. 